in Berkeley, California, and his colleagues designed their bacterium to produce four enzymes that digest cellulose and hemicellulose in switchgrass (Panicum virgatum) that has been pretreated with ionic liquids. They introduced into the E. coli three biochemical pathways that turn sugars into either fuel or fuel precursors for petrol, diesel and jet engines.

Further improvements, such as finding more and better enzymes, are needed to boost biofuel yields, the authors say.

Proc. Natl Acad. Sci. USA http://dx.doi.org/10.1073/ pnas.1106958108 (2011)

\section{ECOLOGY}

\section{The collapse of an invasive ant}

Ecologists in New Zealand feared the worst when they first found the Argentine ant - one of the world's most invasive species - in the country in 1990. But their fears were overblown: by 2011, the ants (Linepithema humile, pictured) had disappeared, without any known human intervention, from $40 \%$ of the sites sampled by Meghan Cooling and her colleagues at Victoria University of Wellington.

Early this year, the researchers examined 150 sites and compared their findings with records from the time of the ants' first appearance. They calculated that Argentine ant populations had survived for an average of 14 years. At sites where the invasive ants had disappeared, resident ant populations were showing signs of recovery.

Furthermore, a climatechange model predicted that rising temperatures and

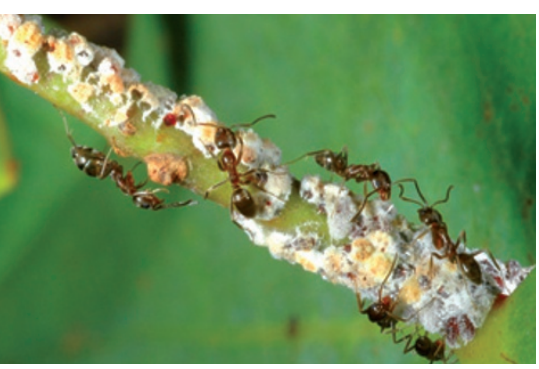

declining rainfall will boost Argentine ant survival by only a few years - hardly a substantial increase on an ecological timescale. Biol. Lett. http://dx.doi.org/ 10.1098/rsbl.2011.1014 (2011)

\section{DEVELOPMENTAL BIOLOGY}

\section{Stem cells from the heart}

The hearts of mice contain a trove of adult stem cells. These resemble the mesenchymal stem cells found in bone marrow and other tissues, which can transform into bone, muscle or fat.

Richard Harvey at the Victor Chang Cardiac Research Institute in Darlinghurst, Australia, and his team isolated the cells in the hearts of adult and developing mice. The heart stem cells can divide repeatedly over long periods in culture, and bear surface proteins that resemble those found on other mesenchymal stem cells. Other experiments suggest that the heart stem cells develop from the same cells that form the heart during development. The study showed that the cells could develop into tissues including fat, cartilage and muscle.

It is unclear whether the stem cells naturally regenerate heart tissue, but they might provide a source of certain cell types for cardiac repair, the authors say. Cell Stem Cell 9, 527-540 (2011)

\section{APPLIED PHYSICS}

\section{Moving micro magnets}

Researchers in Germany have developed a sensor that can detect tiny magnetic signals. Applications for such a device could include helping to diagnose disease by detecting magnetically labelled substances in the body.

The sensor picks up very small signals from low-frequency magnetic fields. Franz Faupel at the University of Kiel and his colleagues made it by coating an oscillating cantilever

COMMUNITY CHOICE

\title{
Pathogens put the pressure on
}

\section{AIGHLY READ \\ on www.plosgen etics.org in November}

Pathogens have driven genetic adaptation in humans more than climate or diet has. Matteo Fumagalli, now at the University of California, Berkeley, and his colleagues calculated the frequency of different genetic variants in more than 1,500 people across 55 populations. They then developed a statistical model to predict the distribution of these variants across the populations. The model incorporates three potential selective pressures on the human genome: climate, diet regimes and pathogen load. Genetic variation correlated most strongly with local pathogen diversity.

Nearly one-quarter of the 103 genes most closely linked to pathogen diversity are involved in immunity. Many also seem to increase susceptibility to autoimmune diseases such as multiple sclerosis and type 1 diabetes. The authors suggest that adapting to cope with pathogens has made humans susceptible to autoimmune diseases when those pathogens are absent. PLoS Genet. 7, e1002355 (2011)

For a longer story on this research, see go.nature.com/d4es $4 \mathrm{~b}$

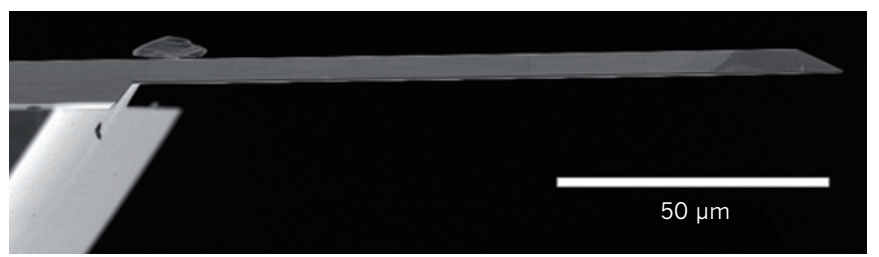

(pictured) with a material that changes shape in a magnetic field. This causes the cantilever to move at different frequencies as the magnetic field changes. A laser measures the cantilever's movement.

The device works at room temperature and does not require the external magnetic field that other magnetosensors need to detect small signals.

Appl. Phys. Lett. 99, 223502 (2011)

\section{ECOLOGY}

\section{Bacteria pass through plants}

Rickettsia bacteria are found in many animals, and are sometimes spread by bloodfeeding insects. But the bacteria can be found in herbivorous insects too - because, it turns out, they can be transferred between insects via plants.
Einat Zchori-Fein at the Agricultural Research Organization in Ramat-Yishay, Israel, and her colleagues found that whiteflies (Bemisia tabaci) lacking the bacteria that were kept in isolation on the same leaf as those carrying Rickettsia acquired the bacteria within days. The team also show that the bacteria are present in the leaves of plants such as cotton and basil, where they survive in the phloem cells that carry nutrients, apparently without harming the plant.

The authors suggest that plants may also mediate the transmission of other bacteria that reside within insects.

Proc. R. Soc. B http://dx.doi.org/ 10.1098/rspb.2011.2095 (2011)

\section{$\rightarrow$ NATURE.COM}

For the latest research published by Naturevisit:

www.nature.com/latestresearch 